\title{
PELATIHAN DAN PENGEMBANGAN SULAMAN DAN BORDIR SEBAGAI PRODUK DESAIN INTERIOR DI KOTA PAYAKUMBUH
}

\author{
${ }^{1) *}$ Mitayani, ${ }^{1)}$ Febriyanti, ${ }^{2)}$ Sri Zulfia Novrita, ${ }^{3)}$ Zulmardi \\ 1)* Program Studi Ilmu Keperawatan, STIKes MERCUBAKTIJAYA Padang \\ ${ }^{1)}$ mitayani_dd@yahoo.co.id 1) febriyanti16011@gmail.com \\ ${ }^{2}$ Program Studi Kesejahteraan Keluarga Universitas Negeri Padang \\ ${ }^{2)}$ srizulfianovrita@yahoo.co.id \\ ${ }^{3)}$ Fakultas Kehutanan, Universitas Muhammadiyah Sumatera Barat \\ ${ }^{3)}$ zul6656@gmail.com
}

*Coresponding author/Email: mitayani_dd@yahoo.co.id

\begin{tabular}{|c|c|}
\hline Informasi Artikel & Abstrak \\
\hline $\begin{array}{l}\text { Diterima Redaksi: } 26 \text { August } 2019 \\
\text { Revisi Akhir: 01 Sept } 2019 \\
\text { Diterbitkan Online: } 27 \text { Sept } 2019 \\
\text { Kata Kunci } \\
\text { pelatihan, pengembangan, sulaman dan } \\
\text { bordir, produk desain interior } \\
\text { Korespondensi } \\
\text { No. HP: } 081363403051\end{array}$ & $\begin{array}{l}\text { Lembaga Keterampilan dan Pelatihan (LKP) "Lemos" yang ada di Kota } \\
\text { Payakumbuh bergerak di bidang sulaman dan bordir dengan } 15 \text { (lima } \\
\text { belas) anggota kursus. Pelatihan dan pengembangan perlu dilakukan pada } \\
\text { lembaga ini karena beberapa hal: (a) Kurangnya tenaga terampil dan } \\
\text { kreativitas dalam membuat hasil kerajinan, penerapan atau aplikasi } \\
\text { produk sulaman dan bordir yang masih terbatas (b) Teknik komposisi } \\
\text { warna dan motif dan pola relatif tidak berkembang. (c) kesuliatan } \\
\text { lembaga untuk mengikuti pelatihan maupun workshop pengembangan diri } \\
\text { terkait dengan keterbatasan dana. Metode Pengabdian adalah berupa } \\
\text { pelatihan pembuatan motif dan pola dasar dan pengembangan inovasi } \\
\text { sulaman dan bordir dari pakar dan ahli. Hasil pengabdian adalah } \\
\text { melakukan pelatihan dan workshop terhadap anggota lembaga mitra } \\
\text { dengan melibatkan Sanggar Kegiatan Belajar (SKB) Kota Payakumbuh } \\
\text { guna meningkatkan mode dan motif sulaman dan bordir, kuantitas dan } \\
\text { kualitas produk dalam mengembangkan hasil produk sulaman dan bordir. } \\
\text { Hasil lainnya adalah pemberian materi tentang keselamatan kerja dan } \\
\text { motivasi dalam bekerja. Peningkatan dalam menghasilkan mode dan motif } \\
\text { sulaman dan bordir dari peserta pelatihan diperoleh kriteria sangat baik } \\
58 \% \text { dan inovatif } 60 \% \text {. }\end{array}$ \\
\hline
\end{tabular}

\section{PENDAHULUAN}

\subsection{Analisis Situasi}

LKP " Lemos" merupakan salah satu lembaga Keterampilan dan pelatihan yang ada di Kota Payakumbuh tepatnya di kelurahan Payobasung Kecamatan Payakumbuh Timur yang bergerak di bidang sulaman dan bordir. Lembaga Kursus dan Pelatihan ini berdiri sesuai dengan Surat Keputusan Dinas Penanaman Modal Pelayanan Terpadu Satu Pintu Nomor: 035/I/SITU/DPMPTSP/PYK-2018 tentang tempat usaha: Kursus Sulaman dan Bordir pimpinan Yuli Fitri yang beranggotakan lebih kurang kurang 7 orang. Anggota lembaga sulaman dan bordir ini sering disebut dengan istilah "anak jahit". Menurut
Adiputra et all (2014), kebanyakan pengrajin melakukan usahanya secara mandiri dengan melibatkan ibu-ibu rumah tangga lainnya sebagai pekerjaan sampingan untuk membantu menambah pendapatan keluarga [2]. Lokasi lembaga ini lebih kurang $10 \mathrm{~km}$ dari Kota Payakumbuh dan $102 \mathrm{~km}$ dari perguruan tinggi pengabdi yang berada di Kota Padang . Berdasarkan hasil obervasi dan wawancara pengabdi kepada pimpinan lembaga dan masyarakat sekitar, persoalan mitra yang mendasar adalah:

\subsection{Permasalahan Mitra}

Persoalan yang terlihat dalam pengembangan usaha ini adalah dari segi kelompok pengrajin 
sulaman dan bordir masih kurangnya tenaga terampil dalam mewujudkan hasil kerajinan sehingga pengembangan kreativitas dikalangan pengrajin sulit terpenuhi, aplikasi produk masih terbatas pada pembuatan bahan baju, mukena dan jilbab sehingga harga jual sudah bisa ditebak sesuai standar harga pasar, tekhnik komposisi warna dan motif masih menggunakan pola yang sederhana dan cenderung monoton, sehingga perkembangan motif dan pola relatif tidak berkembang serta suulitnya bagi lembaga untuk mengikuti pelatihan maupun work shop pengembangan diri terkait dengan keterbatasan dana, karena pengelolaan lembaga permodalan bersumber pada dana mandiri. Dari segi bahan baku, Alat dan proses pembuatan, penggunaan material utama pembuatan sulaman dan bordir masih mengandalkan dari luar kota seperti Bukittinggi dan Jakarta, proses pembuatan masih membutuhkan waktu yang lama, sekitar satu bulan lebih untuk satu stell bahan baju maupun mukena, sehingga harga jual tidak sebanding dengan proses kerja selain itu jumlah mesin sulaman dan bordir yang masih terbatas, dengan jumlah tenaga lebih kurang 15 orang, jumlah mesin hanya 7 unit. Kemudian dari segi pemasaran Produk usaha, akibat model, pola dan bentuk yang monoton, menjadi dilema bagi pengrajin dalam memasarkan produk, persaingan dari daerah lain cukup tinggi seperti Bukitinggi dan Pariaman, belum adanya kerjasama atau akses permodalan dengan berbagai pihak oleh pengusaha, sehingga pemasaran menjadi terbatas pada permintaan konsumen.

\section{METODE}

Upaya yang akan dilakukan oleh tim pengabdi terhadap permasalahan mitra adalah melakukan pendekatan terhadap lembaga Kursus dan Pelatihan ini dengan melibatkan pemerintah terkait guna meningkatkan kuantitas dan kualitas produk dan pengrajin sulaman dan bordir khas Payakumbuh ini, diantaranya dengan: Memberikan pelatihan secara berkala dalam jangka waktu pengabdian pada pengrajin dan pengusaha baik dalam tingkat lokal maupun wilayah Sumatera Barat. Membina administrasi keuangan dan usaha, mentransfer teknologi tepat guna dengan memberikan pelatihan pengembangan kerajinan dan sulaman dalam bentuk aplikasi lain berupa sandal, cendera mata, topi, perlengkapan ibadah, sepatu, tas dan lain sebagainya, serta memberikan bantuan peralatan mesin jahit sulaman dan bordir sebagai bantuan untuk kegiatan usaha sehingga memadai dengan jumlah anggota jahit lembaga [1].

Tujuan pengabdian kepada masyarakat ini adalah untuk mengembangkan lembaga dengan memberikan pelatihan dan bimbingan pengembangan desain kepada para pengrajin di lembaga bagaimana merancang produk terapan untuk diaplikasikan pada produk desain interior, memberikan pelatihan dalam pengelolaan administrasi dan managemen pengelolaan lembaga, memadukan sulaman dan bordir sehingga menghasilkan produk dengan corak desain dan produk baru interior dalam komposisi bentuk pakai yang lebih menarik dan bernilai tinggi sesuai konteks dan nilai kearifan lokal serta mengarahkan lembaga dalam proses produksi dengan metode baru, pemasaran dan mitra kerja. Adapun manfaat kegiatan adalah bagi kelompok sasaran pada lembaga mitra terjadinya peningkatan ketrampilan dalam mengembangkan motif dan mode serta inovasi produk sulaman dan bordir di masa datang.

Pelaksanaan pengabdian kepada masyarakat ini dilakukan di Kelurahan Koto Baru Payobasung Kecamatan Payakumbuh Timur, Kota Payakumbuh pada bulan Maret-Juni 2019. Kelompok Masyarakat sasaran dalam pengabdian adalah anggota kelompok dari LKP sebanyak 15 (lima belas) orang. Kegiatan yang dilakukan pada pengabdian ini adalah pengumpulan data dari survey, hasil wawancara kepada mitra, dan observasi lapangan. Data diperoleh berupa data jumlah pengrajin, penghasilan pengrajin dan bagaimana mitra melakukan pemasaran. Persiapan dan inisiasi, pada kegiatan tahap ini dilakukan untuk menentukan narasumber dan materi pelatihan, di samping itu juga melibatkan empat orang mahasiswa dari STIKes MERCUBAKTIJAYA Padang dan dua orang mahasiswa Universitas Negeri Padang. Selanjutnya merumuskan teknis kegiatan yang akan dilakukan untuk pelaksanaan, dilanjutkan dengan pelaksanaan kegiatan dimulai dengan pengenalan, pelatihan, 
pembimbingan dan sosialisasi kepada anggota mitra. Materi yang diberikan adalah penggalian jenis-jenis produk lain dan bentuk pengembangan inovasi produk dengan perpaduan sulaman dan bordir. Tingkat keberhasilan dari pengabdian ini dapat dilihat dari peningkatan keterampilan dan inovasi pola dan motif dari produk sulaman dan bordir yang dapat dihasilkan oleh anggota peserta setelah mengikuti pelatihan.

\section{HASIL DAN PEMBAHASAN}

Tabel 1. Hasil peningkatan ketrampilan peserta pelatihan sulaman dan bordir produk desain interior di Kota Payakumbuh

\begin{tabular}{|l|l|c|c|c|c|c|c|c|c|}
\hline \multirow{2}{*}{ No. } & \multicolumn{1}{|c|}{$\begin{array}{c}\text { Jenis Ketrampilan } \\
\text { Sulaman dan Bordir }\end{array}$} & \multicolumn{4}{|c|}{$\begin{array}{c}\text { Penilaian Sebelum Pelatihan } \\
\text { (orang) }\end{array}$} & \multicolumn{3}{c|}{$\begin{array}{c}\text { Penilaian Sesudah Pelatihan } \\
\text { (orang) }\end{array}$} \\
\cline { 3 - 10 } & & Sedang & Baik & Best & Inovatif & Sedang & Baik & $\begin{array}{c}\text { Sangat } \\
\text { baik }\end{array}$ & Inovatif \\
\hline 1. & Menjahit Jelulur & 10 & 3 & 2 & 0 & 7 & 4 & 3 & 1 \\
\hline 2. & Menjahit Bentuk & 12 & 2 & 1 & 0 & 6 & 4 & 4 & 1 \\
\hline 3. & Sulaman/Bordir Dasar & 12 & 2 & 1 & 0 & 6 & 5 & 2 & 2 \\
\hline 4. & Sulaman/Bordir Suji & 13 & 1 & 1 & 0 & 6 & 4 & 3 & 2 \\
\hline 5. & Sulaman/Bordir Suji Cair & 12 & 2 & 1 & 0 & 6 & 4 & 3 & 2 \\
\hline 6. & Sulaman/Bordir Inovasi & 13 & 1 & 1 & 0 & 8 & 4 & 2 & 1 \\
\hline
\end{tabular}

Kriteria Penilaian:

Sedang

Baik

: sesuai standar sulaman dan bordir

Sangat Baik

: bentuk dan kerapian sulaman dan bordir

Inovatif

: bentuk dan kerapian sulaman dan bordir yang baik

: bentuk dan kerapian sulaman dan bordir terbaik dan berinovasi

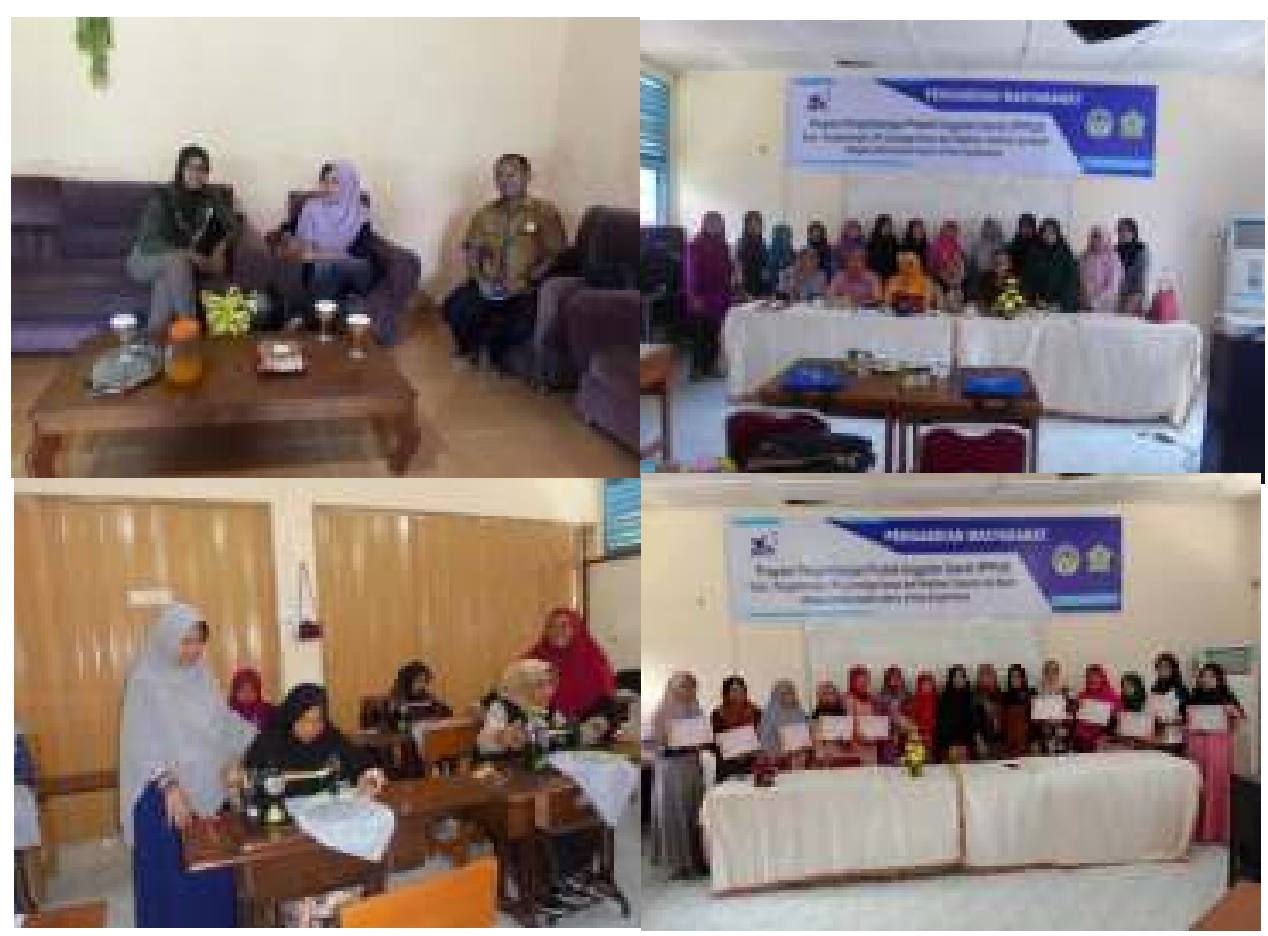


Gambar 1. Survey awal dan diskusi dengan lembaga kursus, pemberian materi pelatihan, praktek ketrampilan sulaman dan bordir dan pemberian sertifikat pelatihan.

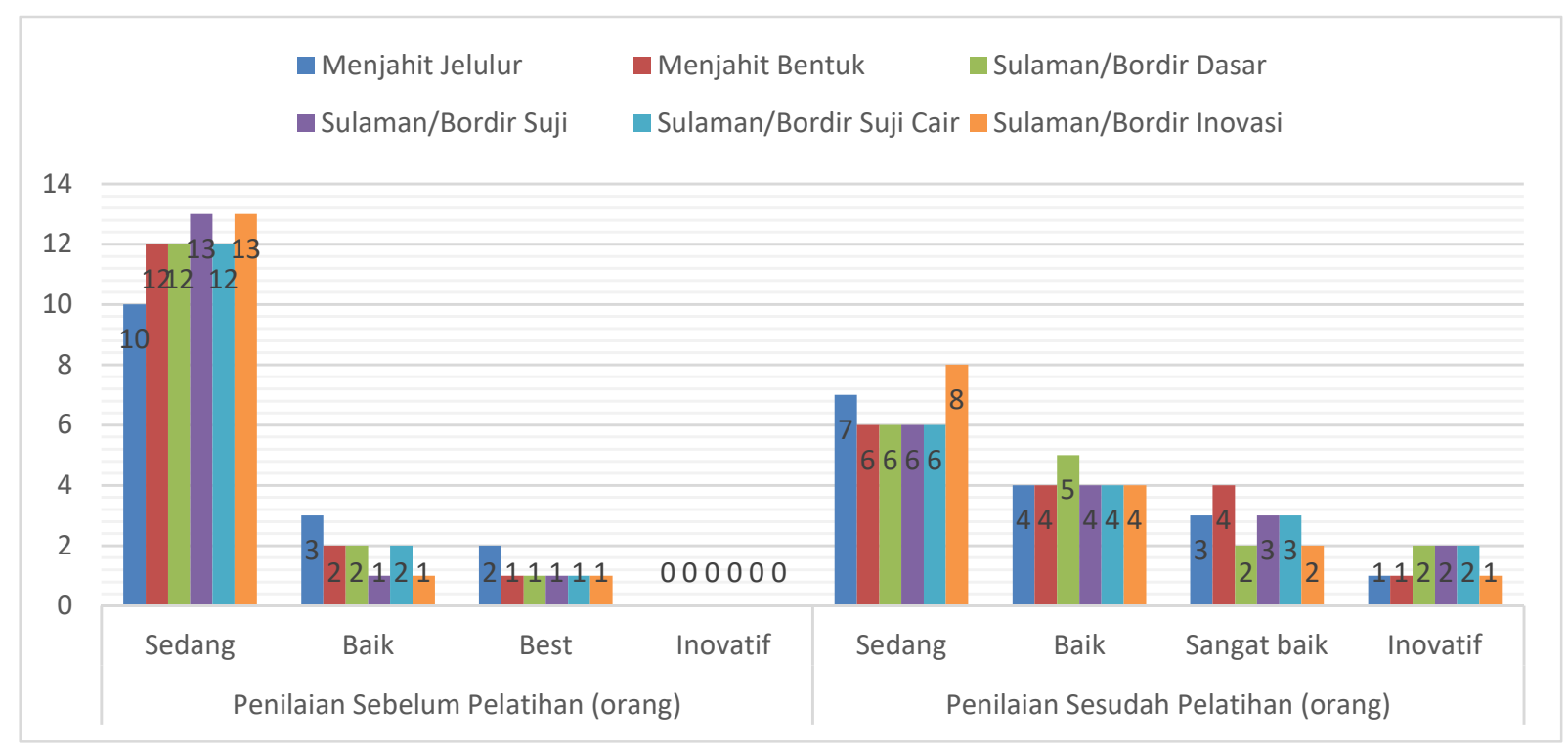

\section{Gambar 2. Hitogram kategori peningkatan keterampilan dan inovasi peserta menghasilkan pola} dan motif dari sulaman dan bordir.

Pelaksanaan pengabdian kepada masyarakat dilanjutkan dengan mengadakan workshop sulaman dan bordir yang dilangsungkan selama tiga hari dari tanggal 18 April sampai dengan 20 April 2019 dimulai pukul 08.00 WIB s.d. pukul 17.00 WIB dalam bentuk workshop. Kegiatan dilaksanakan di Sanggar Kegiatan Belajar (SKB) Kota Payakumbuh, pada hari pertama workshop diawali dengan sambutan sekaligus pembukaan kegiatan oleh Kepala Dinas Pendidikan Kota Payakumbuh Bapak Drs. H.AH. Agustion, M.Pd. Selanjutnya agenda kegiatan diisi oleh tim pengabdian melaksanakan kegiatan workshop tersebut dengan memberikan materi dengan berbagai topik, yaitu: (1) mengapa berwirausaha oleh Mitayani, SST., M.Biomed, (2) Inovasi Desain Sulaman dan Bordir Motif oleh Zulfia Sri Nofrita, (3) usaha sulaman dan bordir dari segi kesehatan oleh Ns. Febriyanti, S.Kep., M.Kep., (5) materi beberapa materi serta narasumber dari tenaga ahli yaitu dari Kepala Sanggar Kegiatan Belajar Kota Payakumbuh dengan topik Wirausaha, dan (6) nara sumber ahli sulaman dan bordir yaitu ibu Neliyarti, MPd. Narasumber ahli yang memberikan pelatihan sulaman dan bordir sudah memiliki berbagai pengalaman unggul dan berprestasi di bidangnya, seperti: telah meraih juara Nasional dalam kreativitas Sulaman dan Bordir, nominasi guru berprestasi Nasional tingkat Provinsi Sumatera Barat tahun 2017, dan sebagai Kepala Lembaga Sulaman dan Bordir Ida di Batusangkar Sumatera Barat. Topik topik yang disampaikan adalah tentang teknik dasar bordir dan sulaman, persiapan alat dan bahan untuk membordir dan menyulam, membuat macammacam tusuk dasar bordir dan jarum sulam, membordir dengan berbagai teknik bordir, pengembangan motif bordir dan sulaman serta Praktik menyulam dan membordir. Kegiatan workshop ini dihadiri oleh tim pengabdi, ketua lembaga Keterampilan, Kepala Sanggar Kegiatan Belajar serta 15 orang peserta atau anak jahit dari lembaga mitra. Dalam pelaksanaannya terdapat penambahan jumlah peserta atau anak jahit di lembaga ini, yang awalnya 7 orang menjadi 15 orang. Fasilitas ruangan pembelajar tim pengabdi bekerja sama dengan Sanggar Kegiatan Belajar Kota Payakumbuh, untuk sarana pembelajaran, transportasi, konsumsi serta akomodasi peserta disediakan oleh tim pengabdi. 
Pada hari ke-2 dan ke-3 dari rangkaian kegiatan workshop dilakukan praktik menyulam dan membordir. Kegiatan praktik ini dilakukan agar materi yang disampaikan dapat langsung di aplikasikan oleh anak jahit yang ada di lembaga. Selain memberikan pelatihan tim pengabdi juga memberikan bantuan peralatan pengembangan sarana berupa mesin jahit sulaman dan bordir digital sebanyak 3 unit, dengan harapan ada pengembangan alat jahit dari manual ke digital, sehingga pengembangan produk yang ditargetkan dapat dicapai.

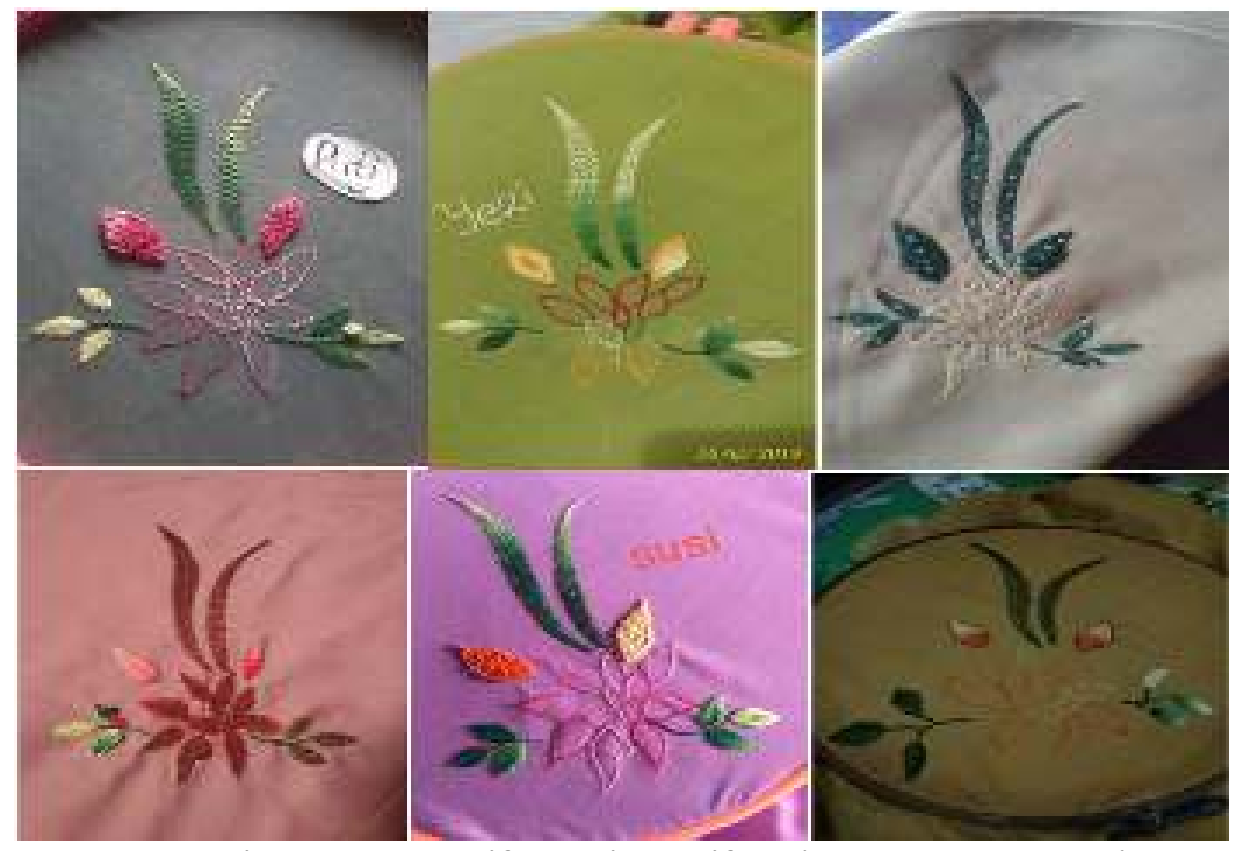

Gambar 3. Beberapa hasil pola dan motif yang inovatif dari sulaman dan bordir

\section{KESIMPULAN}

Dari hasil pengabdian yang telah dilakukan, maka dapat disimpulkan hal-hal berikut:

Pelaksanaan pengabdian kepada masyarakat telah berjalan dengan baik sesuai dengan rencana dan waktu kegiatan yang telah di tetapkan. Pelaksanaan workshop pelatihan sulaman dan bordir bagi peserta telah meningkatkan ketrampilan peserta dalam moif dan pola dari sulaman dan bordir serta menghasilkan inovasi yang diharapkan. Pengembangan keterampilan peserta dapat ditingkatkan dengan penambahan peralatan mesin jahit di lembaga. Penambahan jumlah anak jahit dari 7 orang menjadi 15 orang (52\%)

\section{SARAN}

Dengan hasil yang diperoleh maka diharapkan kepada anggota yang sudah memiliki ketrampilan mengenai pola dan mode sulaman dan bordir yang lebih inovatif dapat membagi ilmu dan melatih anggota masyarakat yang lain atau mengajak untuk bergabung dalam kelompok ini sehingga dapat memberikan ketrampilan dan manfaat yang lebih luas bagi anggota yang baru.

\section{UCAPAN TERIMAKASIH}

Terlaksananya kegiatan pengabdian masyarakat ini, tim pengabdi mengucapkan terima kasih kepada:

a. Kementerian Riset dan Teknologi DIKTI di Jakarta yang telah membiayai kegiatan pengabdian ini melalui Program Pengabdian Masarakat Unggulan Daerah (PPUD) dan Lembaga Layanan Pendidikan Tinggi (LLDikti) Wilayah X Sumbar, Riau, Jambi, dan Kepulauan Riau.

b. Kepala Dinas Pendidikan Kota Payakumbuh, Kepala Sanggar Kegiatan Belajar Kota Payakumbuh, dan Ketua STIKes MERCUBAKTIJAYA Padang.

Semoga semua jerih payah yang telah diberikan semua pihak mendapatkan amal shaleh dan pahala dari Allah SWT, dan bermanfaat bagi kelompok sasaran. 


\section{DAFTAR PUSTAKA}

[1] Adiputra, et all. 2014 IbM. Songket Jinengdalem (Laporan Pengabdian). Lembaga Penelitian dan pengabdian Masyarakat, Universitas Pendidikan Ganesha.

[2] Marianti, M, Istiharini. 2013. Analisis Karakteristik dan Prilaku Konsumen Tenun Songket Palembang (Laporan
Penelitian). Lembaga Penelitian dan Pengabdian Masyarakat, Universitas Khatolik Pahryangan.

[3] Siti Zulfa Yusni 2017. Pengembangan Tenun songket sebagai produk Desain Interior. Lembaga Penelitian dan Pengabdian Masyarakat, Universitas Syah

Kuala. 